\title{
Eusko legegileak Toki autonomiaren inguruan egindako apustua: Toki autonomia Euskadiko Toki Erakundeei buruzko apirilaren 7ko 2/2016 Legean
}

Ortzi de la Quintana Ibáñez

DOI: https://doi.org/10.47623/ivap-rvap.108.2017.10

\begin{abstract}
Aurkibidea: Sarrera.-I. Toki autonomiak Espainako antolamendu juridikoan izandako garapenari buruzko aipamena.-II. Toki autonomiaren kontzeptua: Europako Toki Autonomiari buruzko Hitzarmena eta printzipioaren adierazle nagusiak. II.1. ETAHren Toki Autonomia. II.2. Toki Autonomiaren adierazle esanguratsuenak. - III. Toki autonomiaren babesa Euskadiko Toki Erakundeei buruzko apirilaren 7ko 2/2016 Legea. III.1. Auto-antolakuntza. III.2. Eskumen banaketa. III.3. Herritarren parte-hartzea Udalak jorratzen dituen politiketan. III.4. Udalaren partehartzea beren interesean eragina izan dezaketen politiketan. III.5. Finantza-nahikotasuna. -IV. Ondorioak. -V. Bibliografia.
\end{abstract}

\section{Sarrera}

Euskadiko Toki Erakundeei buruzko Legearen aurreproiektu desberdinak eskuartean izan nituenetik oso interesgarria iruditu zitzaidan Toki Autonomiari ematen zaion garrantzia. Toki autonomia da, udal jardueraren ardatza, horren benetako izaera adierazten duen printzipio orokorra. Printzipio horren garrantzian lanean egon dira nazioarteko erakundeak eta, esate baterako, Europako Demokrazien oinarrizko printzipio bihurtu da, horren inguruan Europako Kontseiluak lan handia egin duelarik.

Ez gara hasiko artikulu honetan Toki Autonomiaren esanahiaren inguruko hausnarketa sakonik egiten, bai ordea printzipio horrek Euskadiko Toki Erakundeei buruzko Legean izan duen eragina eta indarra eman. Hau gauzatuko dugu helburu zehatz eta konkretu batekin: Euskadiko Toki Erakundeei buruzko apirilaren 7ko 2/2016 Legeak(1) (hemendik aurrera ETEL) planteatzen duen toki autonomia eta Estatuaren baitan garatu den toki autonomiaren kontzeptua alderatuz eta ikuspuntu desberdina dagoela zehaztuz; horrela, ETELk toki autonomiaren alde egiten duen apustua argituz.

(1) 2016ko apirilaren 14ko Euskal Herriko Argitaritzaren Aldizkarian argitaratua. 
Helburu honen arrazoia bikoitza da: alde batetik, ETELren bitartez EAEko administrazioan toki erakundeei ematen zaien izaera politikoa (deszentralizazio politikoa deszentralizazio administratiboarekin aurkaratuz) adierazteko; eta bestetik, azken krisiaren ondorioz indarra hartu duten aurrekontu egonkortasunaren eta finantza-nahikotasunaren aurrean toki autonomiak ETELn hartu duen garrantzia adierazteko.

Helburu honekin, lehenik toki autonomia printzipioak Espainiako antolamendu juridikoan izan duen garapenaren inguruko begirada bat egin dugu. Horren arabera toki autonomia deszentralizazio administratibo huts bat bezala garatu da Konstituzio Auzitegiaren 4/1981 Epaiak adierazi zuen bezala. Horrekin batera eta Alemaniako doktrina eredutzat hartuz Konstituzio Auzitegiak 32/1981 Epaiaren bitartez toki autonomia berme erakunde gisa egituratu zuen, eduki ahal zuen izaera politiko guztia baztertuz eta betiko toki autonomiaren izaera markatuz. Interpretazio hori eskuan harturik argitaratu zen Toki Araubide Orokorrari buruzko apirilaren 2ko 7/1985 Legea eta toki erakundeei buruzko doktrina guztia antolatu zen. Baina, 1985ean ere Estrasburgon Europako Kontseiluaren barnean Espainiak Europako Toki Autonomiari buruzko Hitzarmena (hemendik aurrera ETAH) sinatu zuen, eta horretan egituratzen den toki autonomiak berme erakunde huts hori gainditzen du benetako eskubide bat egituratuz. Horregatik, Ian honen bigarren kapituluan ETAHren toki autonomia printzipioa aztertuko da eta hori eskuan hartuta toki autonomia printzipioaren adierazle batzuk zehaztuko dira. Hirugarren atalean ETEL eskuan hartuta aztertuko dira bigarren epigrafean zehaztutako adierazle horiek nola erreflejatzen diren eta horrek argi utziko du zein den Euskadiko Legegileak jarraitzen duen toki autonomiaren printzipioa.

Horrekin guztiarekin, argi geratuko da EAEko legegileak apustu bikoitza egiten duela: batetik, toki autonomia printzipioaren aldekoa, krisiaren ondorioz indarberritutako printzipioak alde batera utzi barik; eta bestetik, ETAHren toki autonomiaren kontzeptua eskuan harturik benetako deszentralizazio politiko baten aldekoa. Kontuan izan behar dugu era berean, ETELk EAEko Administrazio Erakundeen sistema itxi egiten duela administrazio maila guztiak behar bezala arautuz eta egituratuz.

\section{Toki autonomiak Espainiako antolamendu juridikoan izandako garapenari buruzko aipamena}

Espainiako antolamendu juridikoan toki autonomiaren garapena $X X$. mendean zehar ematen dela esan daiteke. Egia esan, XIX. mende osoan zehar Estatuak udalengan zuen kontrol jarduera hain zen handia toki autonomiaren adierazle izan zitezkeen esparru batzuk ere (Udalbatzaren kideak hautatzeko prozedurak, auto-antolakuntza, etab...) indarrik 
gabe gelditzen zirela, benetako autonomiaz hitz egiteko aukera bertan behera geratuz. Zinegotzien hautaketari buruz, udal ordenantzei buruz, udal zergen inguruan, etab... hitz egin izan zen garai horietan, baina Estatuaren kontrola udal jarduera horietan hain zen handia, udal autonomiaren inguruko ahalegin guztiak gutxietsita gelditzen zirela. Zuzenean toki autonomiari buruz hitz egin zuen lehenengo araua 1924ko Udal Estatutua izan zen, eta, halabeharrez Estatu Diktadura baten barnean, hala nola Primo de Riveraren diktaduran, emandako araua izan zen. Egia da toki autonomia hori ez zela benetakoa, ordezkaritza demokratikorik gabe (2) jaiotzen zelako, baina printzipioz auto-antolakuntzan eta udalaren jarduera naturalean egituratutako udala sortzeko asmoa adierazten zuen. Deszentralizazio prozedura garai horretan hasi zen beraz. Toki Administrazioaren berregituraketa gauzatzeko Jose Calvo Sotelo Jauna Toki Administrazioko Zuzendari izendatu zuten eta honek garaiko adituekin udal lege bat egiteari ekin zion. Aditu horien artean administrazio ikuspuntu batetik esanguratsuena Luis Jordana de Pozas jauna izan zen. Aditu hauen proiektuak deszentralizazioa hartzen du bide moduan eta aurretik egindakoarekin haustura (3) suposatu zuen.

Udal Estatutuaren ostean, 1935ean, Errepublika garaian alegia, Udal Lege berri bat onartzen da, baina Franco Jeneralaren Estatu Kolpeak bertan behera utzi zuen. Diktadura horretan, 1945ean oinarriak jartzen dituen 1955eko Toki Araubideari buruzko Legeak argitaratu zen, baina horrek ez zuen toki autonomiari buruzko aipamenik egiten, bai ordea Estatuak udalen gainean egiten zuen kontrolaren inguruan. Diktaduraren azken urteetan toki araubidea aldatzeko urratsak ematen hasi ziren, baina prozesu demokratizatzailearekin bertan behera geratu ziren ahalegin desberdinak. Azkenean, Diktadura eta gero, 1978.urtean Espainiako Konstituzioa onartu zen.

Esan bezala, 1978ko EK diktadura baten osteko konstituzioa da, horrek ekarri zituen beldur eta muga guztiekin. Dakigunez konstituzio honek "trantsizio" deituriko epe baten emaitza nagusia da eta Estatu autokratikotik Estatu demokratikora igarotzeko bidea ireki(4) edo bultzatu zuen. Konstituzio honek, Espainiako Erresuma Zuzenbideko Estatu Demokratiko eta Soziala aldarrikatzen du, eta, autonomia du horren ardatzetariko bat. Nazio bakar horretan autonomiarako eskubidea zabaltzen zaie lurraldeei

(2) ORDUÑA REBOLLO, E., eta COSCULLUELA MONTANER, L., Historia de la legislación de régimen local, lustel, 1 edizioa, Madril, 2008, 198. orrian

(3) ORDUÑA REBOLLO, E., eta COSCULLUELA MONTANER, L., Historia de la legislación de régimen local, lustel, 1 edizioa, Madril, 2008, 199. orrian

(4) Kontuan izan behar dugu benetako irekiera eman zuen legea Politikaren Erreformarako Legea izan zela, horrekin batera alderdi politikoak legeztatu eta lehenengo hausteskunde "demokratikoak» egin zirelako. 
eta nazionalitateei eta, horrekin batera, autonomia eredu horren barnean, toki autonomia bera aldarrikatzen da, nahiz eta intentsitate berdinarekin ez egin.

Espainiako Konstituzioan toki autonomiaren printzipioa ez da berenberegi jasotzen, baina bai toki autonomiaren babesa. Konstituzioaren VIII. titulua, lurralde antolakuntzari buruzkoa, 137. artikuluan argi jasotzen ditu udalaren funtsezko bi ezaugarri: alde batetik, udala estatuaren lurralde antolaketaren oinarria da, probintziekin batera, eta eratzen diren autonomi erkidegoekin batera; eta bestetik, udalek beren intereserako gaiak kudeatzeko autonomia daukate. Beraz, zuzenean EKk udalen toki autonomia printzipioa aipatzen du, toki autonomia esamoldea beren-beregi jaso barik. Horrez gain, titulu berdineko II. kapituluak, toki administrazioari dagokion kapitulua alegia, 140. artikuluan printzipio hori errepikatzen du Estatua toki autonomiaren bermatzaile gisa bere burua agertzen duenean: "Estatuak udalerrien autonomia bermatzen du. Horiek pertsonalitate juridiko osoa izango dute...".

Eginkizun bermatzaile horretan 140. artikuluak toki autonomiaren ezaugarri garrantzitsuei buruzko lehenengo aipamen zuzenak egiten ditu, udal auto-antolakuntza printzipioa aipatu, eta udalbatzaren egituraketa, printzipio demokratikoetan oinarritzen du. Zentzu horretan, argi aipatzen da udalbatzaren kideak sufragio unibertsalaren, berdinaren, askearen, zuzenaren eta sekretuaren bitartez aukeratuko direla.

Azkenik, EKren 142. artikuluak autonomiarekin zuzenean harremanetan dagoen finantza-nahikotasunaren inguruan hitz egiten du, bi printzipioak (toki autonomia eta finantza-nahikotasuna) harremanetan jarriz. Azken finean, udalek haien eskumenekoak diren menpeko atribuzioak aurrera atera ahal izateko beharrezko baliabideak behar dituzte eta horrela, autonomia barik finantza-nahikotasunak ez dauka zentzurik eta finantza-nahikotasunik gabe autonomiak ez du inolako etorkizunik, garatzeko aukerarik ez duelako izango.

Hala eta guztiz ere, 1978ko EKk ez ditu udalen berezko interes horiek zeintzuk diren definitzen eta dena geratzen da zehaztu gabeko kontzeptu juridiko baten menpe. Are gehiago, 1978ko EKren eskumenak banatzean ez du udalaren aipamenik egiten, eta are gehiago, udalen eskumen eta atribuzio banaketa lege lerruneko arauen bitarteko garapena baimentzen du, udalaren pisu konstituzionala guztiz murriztuz, eta, toki autonomiaren muga bihurtuz. Azkenik, lege lerruneko arauaren beharra lege arruntaren bitartez eskumen banaketa egiteko aukera zabaltzen du eta horrela izan da EKaren 149.1.18 eta 149.1.14 artikuluen menpe geratuz. Konstituziogilearentzat gaia ez zen garrantzitsua izan, udalerrien eskumen banaketa administrazioaren araubide orokorraren barnean sartzen duelako (deszentralizazio administratibo huts bat bezala ulertzen zenaren seinale), eta lege arruntaren eskuetan utziz. Kontuan izan behar dugu EKk eskumen banake- 
taren inguruan lege organikoaren beharra ez duela zehazten eta horregatik udalei eskumenak lege arrunten bitartez eman dakizkieke, bai Estatuko legeen bidez bai autonomi erkidegoetako legeen bidez.

Argi geratzen da toki autonomiaren kontzeptua ez dela EKn garatzen; aipatu bai, baina interpretazioaren menpe utziz, printzipioaren aipamen kontzeptuala erabili barik. Beraz, horren definizioan eta zehaztapenean Konstituzio Auzitegia (hemendik aurrera KA) sartu zen. Lan horretan KAren 4/1981 epaia izan zen lehenengoa toki autonomiaren inguruko terminoa zehazten eta horren inguruko interpretazio konkretua egiten: Epai horren arabera, toki autonomia, autonomia administratiboa da eta ez politikoa, azkeneko autonomia politiko hori bakarrik aitortu zitzaielako Estatuari (5) eta Autonomi Erkidegoei, hau da, lege lerruneko arauak egin ahal zituzten erakundeei. Hau horrela, epaiaren arabera, lege lerruneko arauak egiteko gaitasuna duten erakundeek bakarrik izango dute autonomia politikoa, kontuan izan barik, SÁNCHEZ SAEZek adierazi zuen moduan, momentu historiko batzuetan udala izan dela instantzia politiko bakarra (6).

Toki autonomiaren interpretazio horretan, toki autonomia printzipioa autonomia administratibo huts bat bezala egituratzen da, inolako izaera politikorik gabe. Horrez gain, toki autonomia Estatuko eta Autonomi Erkidegoko legegilearen menpe geldituko da, bi horiek izango direlako, EKren eskumen banaketaren arabera, toki administrazioei eskumenak emango dizkiotenak, toki administrazioen ardurapeko gaiak edo intereseko gaiak jorratu ahal izateko. Azkenik, toki autonomia eskubidea, konstituzio printzipio oso bat izan beharrean, Alemaniako doktrinatik zehaztutako erakunde berme (7) bat bezala egituratu egin zen. Zentzu horretan, ez da zehatz-mehatz zehazten zein den toki autonomiaren ukitu ezineko edukia, baizik eta ezagutzen dena interpretatuz, hau da, orokorrean udal bezala ezagutzen dena izango da udala, zer den benetan zehaztu barik eta horren edukia ezagutza orokorraren menpe utziz.

KAren interpretazio horretan berme erakunde baten aurrean aurkitzen gara, eta ez "benetako» eskubide baten aurrean, ondorioz, berme erakunde hori toki autonomiaren muga bihurtuz. Baina, bestetik, toki autonomiaren euskarri diren eskumen banaketari dagokionez, EKk lege arrunten menpe uzten du eskumen banaketa eta toki administrazioaren

(5) Estatuaren kasuan autonomiaz hitz egin beharrean subiranotasunaz hitz egin beharko genuke.

(6) SÁNCHEZ SÁEZ, A.J., Autonomía Local y Descentralización, Su naturaleza jurídica, Tirant Loblanc, Valentzia, 2008, 23 orria.

(7) Berme erakunde kontzeptu hori KAren 32/1981 Epaiak zehaztu zuen hurrengo moduan: «Por definición, la garantía institucional no asegura un contenido concreto o un ámbito competencial determinado y fijado de una vez por todas, sino la preservación de una institución en términos recognoscibles para la imagen que de la misma tiene la conciencia social en cada tiempo y lugar.». 
izaera bifrontearen teoria sortu zen. Horren arabera, Estatuak eta Autonomi Erkidegoek udalei eskumenak legeen bidez emango dizkiete eta eskumenak bi erakundeetatik jasoko dituzte, beraz, toki administrazioek. Bi frenteetatik, bada, jasoko dituzte eskumenak jasoko dituzte udalek, baina eskumen banaketa horretan konstituzio blokea errespetatu beharko dute. Horrela aipatzen dute beren-beregi toki administrazio mailan garrantzi handikoak diren KAren 214/1989 epaiak eta AGren 2001eko otsailaren 21eko Epaiak.

Izaera bifronte horrek berme erakundea bi lurralde erakunde desberdinen artean banatzera behartu du. Estatuak eta Autonomi Erkidegoek errespetatu beharko dute berme erakundea haien eskumen banaketa egiterakoan. Doktrinaren eta jurisprudentziaren interpretazio guzti horiek eragin zuzena izan zuten Toki Araubidearen Oinarriei buruzko apirilaren 2ko 7/1985 Legean (hemendik aurreraTAOL) eta horren aldaketa ugarietan eta noski 1988tik aurrera Toki Ogasunei buruzko arau ezberdinetan ere.

TAOLaren 7. artikuluak udal eskumenak, berezkoak eta delegatuen artean banatu zituen, baina horiez gain, berezkoak ez ziren bestelako eskumenak jorratzeko aukera ematen zuen. Horregatik 25. artikuluan zehaztu egiten ziren zeintzuk gaietan Estatuak eta Autonomi Erkidegoek eskumenak eman behar zizkieten udalei, zerrenda irekia egituratuz; baina artikulu horren lehenengo paragrafoan klausula orokor bat ezartzen zen udalen alde, haien interesekoak diren gai guztiak jorratzeko aukera zabalduz. Horrekin bat zetorren gaitasun orokorreko klausula indartzen zuen 28. artikuluak (8). Bestetik 26. artikuluak ezartzen zituen zeintzuk ziren gutxienez udalek eman behar zituzten zerbitzu publikoak, toki udalen populazioaren gaineko sailkapen bat eginez.

Beraz, TAOLak zehazten zituen: alde batetik, zeintzuk ziren gutxienez udalek eman behar zituzten zerbitzu publikoak; bestetik, zeintzuk gaietan Estatuak eta Autonomi Erkideagoek udalei eskumenak eman edo aitortu behar zizkieten; eta azkenik, berezko eskumenak ez diren bestelako eskumenak jorratzeko gaitasun orokorra zehazten zen.

Dena den, momentu egokia izan daiteke hau gauza bat argi uzteko: 1985. urtean Espainiak Europako Toki Autonomiari buruzko Hitzarmena (hemendik aurrera ETAH) onartu zuen (nahiz eta 1989 urtera arte EAOean beren argitarapenarekin ez sartu estatuko antolamendu juridikoan) eta hitzarmen horretan ematen den toki autonomiaren ikuspegia nire uste apalean eta LASAGABASTER HERRARTE irakaslearekin bat eginez, ez da Espainiako doktrinak edota jurisprudentziak egin duena. ETAHean toki

(8) JIMÉNEZ ASENSIO maisuak askotan adierazten duenez 28. artikulu horretan eskumen osagarriak zehazteko aukera zabaltzen zuen. 
autonomiaren definizioa 3. artikuluan jasotzen da, eta, printzipioa gaitasun eragingarria duen eskubide bezala egituratzen du (9).

Baina hori ez da izan Estatuaren tesia, eta toki autonomia printzipioa autonomia administratibo bezala bakarrik ulertu du. Toki autonomia eta udala, administrazio deszentralizazio bezala ulertu da eta horregatik urteetan zehar 1981ean KAk zehaztutako izaera izan du, ETAHak zehazten duen eskubidea alde batera utziz, eta hitzarmenak berak, 12. artikuluan ezartzen duen malgutasun klausularen(10) interpretazioa aukeran. Geroago azalduko denez, malgutasun klausula honi esker Estatuek ETAHk zehazten dituen 20 konpromisoetatik 10 bakarrik hartu behar ditu Europako Kontseiluaren barneko toki autonomiari buruzko egituretan parte hartzeko.

Inguruabar honetan ez dugu ahaztu behar EKn toki autonomia eta finantza-nahikotasuna eskutik lotuta doazela, hau da, euren intereseko gaiak jorratzeko aukera izateko beharrezko baliabideak bermatu behar zaizkie toki administrazioei.

XXI. mendearen hasierarekin, toki autonomia printzipio horren interpretazioan sakontzen hasteko pausuak ematen zirela zirudien, bigarren deszentralizazioa(11)deitu zena materializatzeko asmoz. Zentzu horretan, KAari buruzko Lege Organikoan aldaketak eman ziren eta Toki Autonomiaren babeserako Helegitea sortu zen. Bestetik, 2005an Toki Administrazioaren Erreformarako Liburu Zuriak toki autonomian sakontzeko betebeharra ezartzen zuen, udalaren eskumen esparrua zehazteko eta finantzazioa zehazteko asmoarekin. Horren ostean, 2006an Toki Administrazioari buruzko Aurreproiektu berria sortu zen; baina, proiektu horrek ez zuen aurrera egin. 2008an munduko krisi ekonomikoaren eraginez, asmo guzti horiek bertan behera gelditu ziren, eta, kontrako bidea hartu zen.

Krisi ekonomikoa erakunde krisi baten bihurtu zen eta Europako Batasunetik Espainiari murrizketak egiteko betebeharra ezarri zitzaion. Helburu horrekin, Estatuak EKren 135. artikulua aldatu zen eta 2001. urtean zehaztutako aurrekontu egonkortasun eta finantza-jasangarritasun printzipioek garrantzi handiagoa hartu zuten 2011. urtean. Horiekin 2/2012 Lege Organikoa indarrean sartu zen eta horrek udal jardueran eragin zuzena izan zuen.

Badirudi momentu horretatik aurrera toki autonomia printzipioa aurrekontu egonkortasun eta finantza-jasangarritasun printzipioen menpe geratu dela, edo horiekin alderatuz, garrantzia galdu duela, eta horren ondo-

(9) ETAHaren 3. artikuluak hurrengoa dio: «Toki autonomiatzat hurrengoa ulertu behar da: Toki erakundeek gai publikoen zati garrantzitsu bat antolatzeko eta kudeatzeko eskubidea eta gaitasun eragingarria, beti ere legearen barruan, euren erantzukizunpean eta herritarren onuran».

(10) ETAHaren 12. artikuluak baimena ematen die Estatu sinatzaileei hitzarmenak zehazten dituen konpromiso guztietatik 20 aukeratzeko beren atxikipena eragingarria izateko.

(11) Lehenengo deszentralizazioa autonomi erkidegoei dagokiona da eta bigarren deszentralizazioa toki administrazioari dagokiona. 
rioz, toki administrazioei horrekin lotutako hainbat betebehar ezartzen zaizkie, toki administrazioen gaineko zaintza berrindartuz. Ugariak izan dira azken bost urteetan Estatutik toki administrazioaren zaintza indartu dituzten legeak: gardentasunari buruzko legeria, kontratu publikoei buruzko legeria, Diru-laguntzei buruzko legeria, etab. Hain handiak izan dira Estatu zaintza indartu duten lege erreformak, alderdi politiko askotik birzentralizazio prozeduratzat jo izan dela lege jarduera.

Guzti honen hizpide izan da CORA batzordearen gomendioekin bat etorriz proposatutako Toki Administrazioaren Arrazionalizazio eta Jasangarritasunari buruzko 27/2013 Legea. Arrazionalizazio Lege horren helburu nagusia Toki Araubidearen Oinarriei buruzko Legearen eta Toki Ogasunei buruzko Legearen erreforma izan zen. Toki Ogasunei buruzko erreformari dagokionez, 2/2012 Lege Organikoaren aurrekontu egonkortasun eta finantza-jasangarritasun printzipioek izango duten garrantzia ezartzen dute eta aurrekontu egonkortasuna, gastu araua eta zor biziaren kontrolerako sistema indartzen dute, besteak beste. TAOLri dagokionez, esan daiteke sistemaren aldaketa bat egiten dela.

TAOL berriak (erreformaren ostean gelditzen den TAOL) bertan behera uzten ditu gaitasun orokorrerako klausula guztiak, 25.1. artikulua aldatu egiten du, eta 28. artikulua indargabetu du. Ez dugu jakingo erreforma hori udal eskumenak argitzeko asmoarekin edo udal jarduera murrizteko helburuarekin egin zen. Laugarren paragrafo bat sartzen da 7. Artikuluan, eta berezkoak ez diren bestelako eskumenak definitzen dira, horiek egikaritzeko sistema berri bat arautuz. Udalek eskumen horiek gauzatu ahal izango dituzte, finantza-jasangarritasunaren inguruan finantza-zaintza organoek euren aldeko txostena egiten badute eta beti ere bikoiztasunik ez baldin bada ematen. Zaintza funtzioak indartu egiten ditu 27/2013 Legeak eta TAOLean finantza-zaintza organoek txosten ugari egin behar dituzte eskumen bikoiztasun eta jasangarritasunaren kasuetan, udal bateratze edo zatitzearen kasuetan, etab.

TAOLaren erreformak eztabaida handiak piztu zituen toki administrazioetan: zerbitzuen kostu eragingarria, jasangarritasuna, aurrekontu egonkortasuna, eta orokorrean, toki autonomiaren kaltetan joaten ziren zaintza funtzio guztiak direla eta. Bide horretan, erreformaren aurkako helegite ugari jarri dira KAan eta dagoeneko 2016ko maiatzean lehenengo epaiak atera dira (12). Horien artean KAren 41/2016, 111/2016, 168/2016 eta 180/2016 zenbakidun Epaiak, non finantza-zaintza organoaren esku-hartzea murriztu egiten da (batez ere 26. artikuluko zerbitzuen inguruan adierazten zen txostenaren inguruan) toki autonomiaren aurkakoak direla argudiatuz.

(12) Horietan lehenengoa KAren 41/2016 epaia, 1792/2014 Errekurtso zenbakia. 


\section{Toki autonomiaren kontzeptua: Europako Toki Autonomiari buruzko Hitzarmena eta printzipioaren adierazle nagusiak}

Sarreran adierazi dugun bezala, ez da gure asmoa toki autonomia kontzeptuaren inguruan hausnarketa sakona egitea, baina argi geratu da orain arte toki autonomiak Espainiako antolamendu juridikoan deszentralizazio administratibo huts bat bezala ikusten dela, eta nazioarteko esparruan toki autonomiaren kontzeptuari izaera politikoa eman nahi zaiola, SÁNCHEZ SAEZek esaten duen moduan, Toki Autonomia ezin daiteke geratu denbora gehiago kontzeptu administratibo bezala, izaera politikoa duela argi baitago (13).

Autonomia kontzeptuaren azterketa etimologiko bat eginez, autonomia hitzaren jatorrian bi kontzeptu daude: auto+nomos. Honetan auto hitzaren esanahia zehaztea ez da zaia: berezkoa, berena. Nomos kontzeptuan, aldiz, desberdintasunak ditugu: alde batetik, nomos araua da, araua zentzu zabalean. Eta bestetik, nomos hitza, hesia edo harresia ere bada, hau da, sartzea edo irtetea debekatzen duen mugarria. Bi kontzeptuak oinarrizkoak dira autonomia kontzeptua aztertzeko. Esangura guzti horiek kontuan izanik argi dago autonomia dela bakoitzak beren buruari jartzen dizkion mugak (araua jokaeraren muga bezala ulerturik).

Ikuspegi honetatik oso kuriosoa da autonomiaren kontzeptuaz RAEk ematen duen definizioa: «Potestad que dentro de un Estado tienen municipios, provincias, regiones $u$ otras entidades, para regirse mediante normas y órganos de gobierno propios.» (14). Ahalgo bat bezala definitzen du, eta, izaera administratiboa edo zuzenbide publikoko izaera duen kontzeptu baten inguruan hitz egiten duela pentsa dezakegu. Baina borondatearen autonomiaren definizioari helduz, beste modu baten ere ulertu daiteke: bakoitzak beren arauak ezartzeko aukera, beti ere legearen barnean badaude. Azkeneko kontzeptu hau da alderdi etimologikoarekin harreman handiagoa duena.

PÉREZ LUQUEk autonomiaren kontzeptua aporiatzat jotzen du, hau da, ikuspuntu arrazional batetik beren bideragarritasun eza daukan enuntziatua. Zentzu horretan, PÉREZ LUOUEk(15) esaten duenez, badirudi gaur egun autonomiari buruz hitz egitea ez duela zentzurik, ez duela merezi. Badirudi autonomia dela guztiek faltan botatzen duten gauza, baina behin edukita, inor ez da horren inguruan hitz egiteko gai. Autonomia botere banaketa da, edozein botere bere ahalgoa banatzerakoan autonomia ematen

(13) SÁNCHEZ SÁEZ, A.J., Autonomía Local y Descentralización, Su naturaleza jurídica, Tirant Loblanc, Valentzia, 2008, 79 orria.

(14) Diccionario de la Real Academia de la Lengua Española, edición del tricentenario. www.rae.es.

(15) PÉREZ LUQUE, A, ¿Existe realmente la autonomía local? El consultor de los Ayuntamientos, 14 zkia, 2002ko uztailaren 30etik abuztuaren 14rako hamabostaldia, bigarren liburukia, 2437 orria. 
ari da, eta horrekin boterearen deszentralizazioa gauzatzen da. Boterea banatzen denean, erakunde berriak sortzen dira, eta lurraldeari boterearen zatia ematen bazaio, deszentralizazioaren ondorioz, lurralde erakunde berriek autonomia izango dute.

Benetako autonomia da, deszentralizazioaren produktua, deszentralizazio barik ez dago autonomia eta autonomiarik gabe ezin dezakegu benetako deszentralizazioaz hitz egin. PARADA VAZQUEZi jarraituz, deszentralizazio hori sustatzen duen erakundeak kontrolatu egiten duenean, deszentralizazio teknikoaren aurrean egongo gara, baina ez benetako autonomia dakarren deszentralizazioaren aurrean (16).

Egindako hausnarketa etimologiko horretaz gain, kontuan izan behar dugu autonomiaren kontzeptu hau Zuzenbide munduan zehaztu gabeko kontzeptu juridikoa dela eta arazoa horren zehaztapenean etorri dela. Konstituzio Auzitegiak berak autonomia printzipioa zehaztugabeko kontzeptu juridikoa bezala aitortu du, eta, hori berez arazoa da. Hala, kontzeptu berak ulertzeko interpretazio anitzak izan ditzakeelako, nahiz eta Auzitegi Gorenaren jurisprudentziak askotan esan zehaztu gabeko kontzeptu juridikoek interpretazio bakarra daukatela eta emaitza bakarra eta justua(17) dutela.

Barne ikuspuntu batetik, autonomia auto-antolakuntza ahalgoa da, hau $\mathrm{da}$, erakunde desberdinak autonomoak izateko behar duten lehenengo pausua auto-antolakuntza izango da, erakundearen egituraketa antolatzeko ahalgoa(18). Kanpo ikuspuntu batetik, aldiz, autonomia erakunde horien intereserako gai propioak antolatzeko eta kudeatzeko duten ahalgoa da. Bi ikuspuntuak batera harturik, autonomia izan daiteke autodeterminazio gaitasuna, erakunde baten autogobernua gauzatzeko ahalmena, beren kabuz arazoak konpontzeko erabakia eta beren beharrizanak asetzeko ahalmena (19).

Toki autonomiaren kontzeptuari eusten badiogu, badirudi toki autonomia ezin dela deszentralizazio administratibo huts batean gelditu, haratago joan beharreko gauza bat izan behar dela. Azken bide hori jorratzen du besteak beste Europako Toki Autonomiari buruzko Hitzarmenak (ETAH). Lehen aipatu dugun bezala ETAHren 3. artikuluak(20) toki autonomiari

(16) PARADA VÁZQUEZ, R, Derecho Administrativo I (Organización y empleo público), Marcial Pons, 1988, 196 orr.

(17) AGaren 1987ko urriaren 28ko eta abenduaren 28ko epaiak, edota 1991ko azaroaren 21eko epaia.

(18) ÁlVAREZ RICO, M., Principios Constitucionales de organización de las Administraciones Públicas, Instituto de Estudios de Administración Local, 1987, 37 orr.

(19) PÉREZ LUQUE, A, ¿Existe realmente la autonomía local? El consultor de los Ayuntamientos, 14 zkia, 2002ko uztailaren 30etik abuztuaren 14rako hamabostaldia, bigarren liburukia, 2437 orr.

(20) ETAHaren 3. artikuluak hurrengoa dio: "Toki autonomiatzat hurrengoa ulertu behar da: Toki erakundeek gai publikoen zati garrantzitsu bat antolatzeko eta kudeatzeko eskubidea eta gaitasun eragingarria, beti ere legearen barruan, euren erantzukizunpean eta herritarren onuran». 
izaera politikoago bat ematen dio, berme erakunde huts horretatik eta deszentralizazio administratibotik guztiz aldentzen duena, toki autonomia eskubidetzat hartuz. Zentzu horretan LASAGABASTER HERRARTEk hurrengoa adierazi zuen: "La Carta no pretende establecer solo un principio jurídico que obligue a los estados signatarios a adoptar las disposiciones legislativas necesarias para garantizar la autonomía local. Va más allá, al dar a la autonomía local el rango de derecho. Esta naturaleza jurídica de derecho tiene una serie de consecuencias, entre las que se pueden enunciar: 1) un derecho significa la posibilidad de su exigibilidad, aunque ésta se ve limitada si la norma contraria al derecho tiene naturaleza jurídica de Ley, 2) un derecho exige su concreción con un contenido preciso, 3) la existencia del derecho obliga al establecimiento de mecanismos de defensa para su garantía y 4) el derecho encuentra su principal garantía en el valor que el ordenamiento interno tenga la propia carta.»(21).

\section{II.1. ETAHren Toki Autonomia}

Lan honen hedadura behar bezala ulertzeko derrigorrezkoa dugu Europako Toki Autonomiari buruzko Hitzarmenaren (ETAH) inguruan aipamen berezia egitea. Kontuan izan behar da Euskadiko Toki Erakundeei buruzko apirilaren 7ko 2/2016 Legeak zuzeneko hainbat aipamen egiten dituela ETAHren inguruan. Geroago adieraziko denez, nazioarteko tresna horretan zehazten den toki autonomiaren kontzeptua da Euskadiko legegileak kontuan izan duena, eta haien euskarri nagusienetarikoa; Estatuak egituratutako kontzeptutik aldendu barik, baina esangura zabalagoan eta bermatzaileagoan.

ETAH Europako Kontseiluaren barnean 1985. urtean egindako nazioarteko hitzarmena da, Espainiak 1985eko urriaren 15ean sinatu zuena eta 1988ko urtarrilaren 20an berretsi zuena, EKren 94.1 artikuluak aipatzen duen Gorte Nagusien baimena jaso ostean. Hori bai, REQUEJOS PAGES (22) autoreak adierazten duenari jarraituz, prozedura hori jarraitzeak ez dio ematen ETAHri lege izaerarik, ezta antzekorik ere; nahiz eta, bere ustez, planteamendu hori akastuna izan, arau iturrien aplikagarritasunean zuzeneko eragina duelako. Gogoratu behar dugu nazioarteko hitzarmenak ez direla konstituzio blokean sartzen (23) eta ETAH, eta geroko

(21) LASAGABASTER HERRARTE, I., La Carta Europea de la Autonomía Local, iustel, Madril, 2007.

(22) REQUEJO PAGES, J L., «El valor de la Carta Europea de la Autonomía Local en el ordenamiento español" La autonomía de los entes locales en positivo: La Carta Europea de la Autonomía Local como fundamento de la suficiencia financiera liburuan (CAAMAÑO DOMÍNGUEZ, F Koord.), Ed. Fundación Democracia y Gobierno Local, Madril, 2003.

(23) ETAHren esparruan KAren urriaren 5eko 235/2000 epaiak adierazten du ezaugarri hori. 
beste arau batek, hitzarmena urratzen badu, horrek ez duela araua baliogabetuko; bakarrik bere aplikagarritasunean izango du eragina.

ETAHk 18 artikulu ditu eta horietatik toki autonomiaren muina 2. artikulutik 11. artikulura bitartean bakarrik jorratzen da, hau da, 10 artikulu bakarrik. Beste artikulu guztiek ETAHren indarrari eta onarpenari buruz hitz egiten dute. Horrez gain, ETAHren 12. Artikuluak malgutasun klausula ezartzen du eta, horren arabera, Estatuek ETAHren lehenengo zatiaren 20 ataletatik 10 onartu behar dituzte ETAHren barne egoteko. Hau da, lehenengo hamar artikulu horiek ezartzen dituzten 20 konpromisoetatik 10 bakarrik onartu behar dituzte Estatuek ETAHren baitan sortzen diren egituretan parte hartzeko, eta horiekin suposatuko da Estatu horiek toki autonomiaren babesean jardungo dutela.

ETAHren inguruko izaerari buruzko hausnarketa txikia egin eta gero, eta aurretik aipatu dugun bezala, ETAHk Toki autonomiaren inguruan egiten duen interpretazioa ez da Estatuaren interpretazio berdina. ETAH haratago doa eta toki autonomia eskubide bezala planteatzen du. Horrek esan nahi du, babesteko moduko jarduerak gauzatzeko aukera egon beharko litzatekeela, lehenago LASAGABASTER HERRARTEren eskutik jasotako azalpenekin bat etorriz.

ETAHk toki autonomiaren inguruko definizioa 3. artikuluan egiten du eta artikulu horretatik LASAGABASTER HERRARTEri(24) jarraituz, hurrengo ezaugarriak adieraz daitezke:

- Eskubidea edo gaitasun eragingarria da.

- Gai publikoen zati handi bat kudeatzeko eta antolatzeko asmoa izan behar du.

- Toki erakundeen erantzukizunpean.

- Toki erakundeen herritarren alde.

- Eskubidea egikarituko da sufragio unibertsalaren, askearen, berdinaren, zuzenaren eta sekretuaren bitartez hautatutako bilkuraren bidez.

Adierazpen guzti horiek Europako Kontseiluak egiten ditu Kontseiluaren sorrerako printzipioak babestu ahal izateko. Zentzu horretan, Europako Kontseiluak ETAHren helburu garrantzitsuena bezala hurrengoa adierazten du: Europan komunak diren ideiak eta printzipioak bermatzea, hurrengoak izanik: printzipio demokratikoa eta botere deszentralizazioa. Ikuspuntu horretatik ETAHren 3. artikuluak bi printzipio horiek islatzen ditu.

Beraz, ETAHk toki autonomiaren definizioan deszentralizazio printzipioaren hurrengo adierazleak indartuko ditu: toki autonomiaren egituraketa eskubide bezala, erantzukizun printzipioan oinarritutakoa, toki erakundeen intereserako diren gaiak antolatzeko eta kudeatzeko. Erakunde

(24) LASAGABASTER HERRARTE, I., La Carta Europea de la Autonomía Local, iustel, Madril, 2007. 
deszentralizatu bat bezala egituratzeko betebeharra adierazten da, nahiz eta deszentralizazio hori, Estatuak egiten duen bezala, izaera administratibo hutsa izan. Printzipio hau ETAHren 4.3. artikuluan ere jorratzen da, sorospidezko printzipioarekin batera hurrengoa adierazten duenean: politika publikoen egikaritza herritarrei hurbilen dauden erakundeei egotzi egin behar zaizkie (hurbiltasun printzipioa).

Bestetik, printzipio demokratikoa ETAHk egiten duen beste esamoldeetan ikus daiteke. Artikuluak dio toki autonomiaren bidez toki erakundeen intereserako diren gaiak kudeatu eta antolatuko direla, toki erakunde horietako herritarren alde (hurbiltasun printzipioa) eta gai horiek kudeatu eta antolatuko dira modu demokratikoan aukeratutako hautetsien bitartez. Horrez gain, kudeaketa eta antolaketa horretarako organo exekutiboak eduki dizatkete, zuzeneko demokraziaren inguruko bestelako tresna batzuk erabiltzeko aukera zabalduz.

Argi dago bi printzipio horiek; demokrazia printzipioa eta deszentralizazio printzipioa, ETAHren 3. artikuluan zuzeneko harremana dutela. Harreman estua daukate, eta bata zein bestea elkarrekin ulertu behar dira toki autonomiaren kontzeptua behar bezala ulertzeko.

\section{II.2. Toki Autonomiaren adierazle esanguratsuenak}

Aurreko azpi-epigrafean jorratutako kontzeptua oinarri harturik, ETAHren bestelako azterketa bat egin nahi dugu orain. Testu osoaren irakurketa eskuan dugula eta nazioarteko hitzarmen honen inguruan Europako Kontseiluak beren errekomendazioen bitartez egin duen garapena ikusirik, argi zehaztu daiteke toki autonomiaren inguruan adierazle batzuk daudela, hau da, toki autonomiaren garapen egokia ikusteko adierazleak. ETAHren irakurketatik hurrengo bost adierazle nagusi aipatu daitezke:

-Eskumenak: ETAHren 4. artikuluak argi uzten duenez toki autonomiaren irizpideetariko bat eskumenen banaketa hartzen du ardatz moduan. Zentzu horretan ETAHk toki erakundeen eskumen banaketa legearen bitartez edo konstituzioaren bitartez egitea gomendatzen du, eta eskumen horiek garatzeko askatasun osoa eduki behar dute. Bestetik artikulu berak adierazten duenez, eskumen banaketa egin behar da kontuan izanik zein den herritarretatik hurbilen dagoen erakundea, hau da, eskumenen egikaritza herritarretatik hurbilen dagoen agintaritzaren menpe utzi behar da, eta eskumen horiek orokorrean osoak izan behar dira. Zentzu horretan derrigorrezkoa da Europako Kontseiluaren Ministro Batzordearen 1995eko urriaren 12ko R(95)19E Errekomendazioari aipamena egitea. Errekomendazioak eskumen banaketaren inguruan bi ikuspuntu adierazten ditu: 
eskumen banaketarako irizpide ezberdinak eta elkarbanatutako eskumenen egikaritza harmonizatzeko irizpideak (25).

- Auto-antolakuntza: ETAHren 6. artikuluak ere argi uzten du toki erakundeek euren antolaketarako askatasuna izan behar dutela haien eskumenak behar diren moduan eta haien herritarrei zuzenduta gauza ditzaten. Udal jardueraren kudeaketa eragingarria gauzatu ahal izateko, askatasunak eta eskumenen egikaritza haien herritarrentzako modu egokian definitzeko, askatasunak toki autonomia behar bezala garatzea ahalbideratuko dute. Zentzu horretan, artikulu berdinaren 2. paragrafoak langile publikoen inguruko aipamena ere egiten du, horien hautaketa prozeduretan meritu eta gaitasun printzipioak errespetatuak izan daitezen.

Auto-antolakuntzaren esparruan ere aipatu behar dugu ETAHk elkarte izaera duten erakundeen alde egiten duen aldarrikapena. Zentzu honetan, ETAHren 10. artikuluak adierazten du, toki erakundeek euren eskumenak eta zerbitzuak aurrera ateratzeko elkartzeko aukera dutela, beti ere interes komunekoak baldin badira.

- Herritarren parte-hartzea: Demokrazia zuzenaren inguruan ez dago inolako aipamen zehatzik ETAH osoan, bai ordea herritarren inguruko aipamenak. Prozedura eta antolaketa guztiek herritarren onura bilatzea dute helburu, eta horregatik 3.2. artikuluak ez ditu alde batera uzten herritarren parte-hartze a bermatzeko tresnen zehaztapena. Artikulu horretan adierazten denez, toki erakundeetan sufragio unibertsalaren, askearen, berdinaren, zuzenaren eta sekretuaren bitartez hautatutako organoak osatuko dira, baina ez ditu bertan behera uzten erreferenduma, auzokideen batzak edo bestelako kontsultak egitea.

- Udalak euren intereserako gaien zehaztapenerako parte-hartzea: Honen inguruko aipamenik zuzenena ETAHren 4.6. artikuluan aurkitzen dugu. Artikuluak adierazten duenez, toki erakundeak kontsultatuak izan behar dira horiei eragin ahal dizkieten gai guztien inguruko planifikazioa egiterakoan. Horrekin batera, oso adierazgarria da ETAHren 8. artikulua, horretan adierazten baita zeintzuk izan daitezken toki erakundeek euren jardueran izan ditzaketen kontrolak.

-Finantza-nahikotasuna: ETAHren 9. artikulu luzeak azkenik, udal jarduera gauzatzeko beharrezko baliabideak lortzeko eta bermaturik izateko betebeharra ezartzen du. Udalek ezin dute autonomia garatu finantzazio nahiko barik eta artikulu horrek finantzazio horren inguruan jarduten du. Artikuluaren 1. paragrafoak adierazten du zein den

(25) SÁNCHEZ SAEZ, A.J., Autonomía Local y Descentralización, Su naturaleza jurídica, Tirant Loblanc, Valentzia, 2008, 40 orria. 
Europako Kontseiluaren nahia: «toki erakundeek euren baliabideak modu askean kudeatzeko aukera izatea». Baliabideak proportzionalak izan behar dira eskumenekiko, eta zati baten toki erakundeen zergetatik eta ondaretik etorri behar dira.

\section{Toki autonomiaren babesa Euskadiko Toki Erakundeei buruzko apirilaren 7ko 2/2016 Legea}

2016. urtean indarrean sartu zen Euskadiko Toki Erakundeei buruzko apirilaren 7ko 2/2016 Legea (hemendik aurrera ETEL) eta lege horretan toki autonomiaren kontzeptua, Espainiako antolamendu juridikoa gainditu barik, ETAHk ematen duen kontzeptura hurbiltzen du. Garai hauetan badirudi toki autonomia printzipioaren eremua aurrekontu egonkortasun printzipioaren eta finantza-jasangarritasun printzipioaren aplikazioaren ondorioz bere esparrua murrizten doala. ETELk horiek ahaztu barik toki autonomiari garrantzia ematen dio, toki autonomia deszentralizazio administratibo hutsa izatetik izaera politikora eramanez. Horren harira, ETELren zioen azalpenak zuzen esaten du: «ezinbestekoa da EAEko udalek zuzenean eragiten dieten organoetan eta erabakiak hartzeko prozesuetan egotea, aurrerantzean ez daitezen izan halako tutoretza-mailaren mende dauden administrazioak, tutoretza horrek ez baititu beti errespetatzen udalei dagozkien funtzio garrantzitsuak eta, gainera, tutoretza hori ez baita beti bateragarria udalek bermatuta eduki behar duten tokiko autonomiaren errespetuarekin.». ETELk udalaren izaera demokratikoan oinarritzen du bere aplikagarritasuna eta autonomiarekin batera doazen hainbat artikulu eta xedapen jasotzen ditu.

ETELk berak 9. artikuluan definitzen du zer ulertzen duen toki autonomia printzipio bezala, eta horren definizio zehatza egiten du. Baina hori baino lehen, toki autonomia aipatzen du 4.2.a). artikuluan, udal gobernu jarduera eta zuzendaritza politikoan aplikatu beharreko printzipioak aipatzerakoan. Haratago doa legea eta hurrengo artikuluan, 5.ean hain zuzen, autonomia printzipioaren bermeak aipatzen dituenean, zeintzuk tresna erabiliko diren horren intereserako, eskumenak kaltetzen dituztenean udal partaidetza bermatzeko. ETELak erabiltzen duen hizkera gogora ekartzen digu KAren 32/1981 Epaiaren 2. Oinarri Juridikoan esaten zuena: «derecho de la comunidad local a participar a través de órganos propios en el gobierno y administración de cuantos asuntos les atañe, graduándose la intensidad de esta participación en función de la relación existente entre los intereses locales y supralocales dentro de tales asuntos o materias».

Hau horrela, ETELren 5. artikuluak toki autonomiaren bermea titulupean udalen parte-hartzea bermatzeko sistema bat egituratzen du hurrengo esparruetan: 
- Toki erakundeengan eragina izan dezaketen arauak egiteko prozeduran.

- Programa, proiektu, plan eta politika publikoak egiterakoan.

Eta guzti hori bi ezaugarri komunekin: alde batetik, partaidetza hori EAEko gobernu maila guztietan gauzatuko dela (Lurralde Historikoetan eta EAEan); eta bestetik, toki erakundeen intereserako diren gai guztietan. Azkenik 5.3. artikuluak aipatzen du parte-hartze sistema hori egituratuko dela botere maila bakoitzaren auto-antolakuntzarako ahalgoaren barnean.

Artikulu horren idazketan aipamen esanguratsu eta garrantzitsu bat adierazten da: udalen partaidetza udalek duten eskubide bat da, eta ez eskumen "huts" bat; eskubideak dakarren karga guztiekin, antolamendu juridikoagatik babestua izan daitekeen eskubidea, eta horren defentsa eraginkorra ahalbideratzen duena.

Horrez gain eta toki autonomia definitu baino lehen, egokia ikusten da Euskal legegileak Udalerri moduan zer ulertzen duen adieraztea. Horren definizioa ETELren 8. artikuluaren, II Tituluaren 1. Kapituluan egiten da, bi ikuspuntu desberdin erabilita:

- Legitimitate demokratikoa duen gobernu maila bezala definitzen da.

- Toki gai publikoetan herritarrek duten parte-hartze tresna edo herritarrek parte-hartzeko duten bide bezala.

Artikulu horrek egiten duen definizioaren bi ikuspegiak kontuan hartuz, argi azaltzen da Euskal legegileak Udalerria EAEko oinarrizko lurralde erakunde bezala ulertzen duela, eta horrekin batera toki autonomia ez duela ulertzen deszentralizazio administratibo huts gisa, baizik eta izaera politikoa duen deszentralizazio erakunde bezala, hau da, toki autonomia printzipioaren izaera politikoa aitortzen du. Erakunde politiko gisa ulertzeak adierazten du gobernuak demokrazia modernoetan duen paper bikoitza: alde batetik, administrazioaren burua; eta bestetik zuzendari politiko moduan.

Azkenik, ETELk 9. artikuluan toki autonomia definitzen du:

1.-Udalek autonomia osoa daukate toki-interes publikoko gaiak antolatu eta kudeatzeko, ordenamendu juridikoaren barruan.

2.-Udalen jarduera arauemaile eta betearazlearen berariazko helburua izango da herritarren bizi-kalitatea hobetzea.

3.-Euskal udalek, beren autonomia propioaren eta ordenamendu juridikoak esleitutako eskumenen esparruan, politika propio eta berezituak taxutu eta aplikatu ahal izango dituzte, eta, hala badagokio, dauzkaten baliabideen araberako lehentasunak ezarriko dituzte. 
4.-Udal-autonomiak eduki politikoa dauka eta suposatzen du toki-gobernuek antolaketa- eta kudeaketa-gaitasuna edukitzea zerbitzu-emate hutsetik harago doazen politika-propioak definitu eta gauzatu ahal izateko.

5.-Udal-autonomiak barne hartzen du, betiere, interes publikoak antolatzea udalaren berezko esparruan, bere gobernu-organoak eta administrazioa antolatzea eta kudeatzea, bere lurraldea antolatzea, tokiko zerbitzuak arautzea eta ematea, ekimen ekonomikoa, bere zerbitzupeko langileen inguruko politika eta kudeaketa, ondarea eta diru-bilketa, eta orobat bere ogasunen baliabideak administratzea eta erabiltzea.

6.-Udal-organoek hartzen dituzten erabakiak aurrekontu-egonkortasunaren eta finantza-jasangarritasunaren printzipioetara bilduko dira, beti.

Idazketa horrek ETAHren 3. artikuluak egiten duen idazketa gogora ekartzen du eta hitzarmen horretan toki autonomiari izaera politikoa aitortzen zitzaion. Gogoratu behar dugu eskubide bezala ezartzeak LASAGABASTER HERRARTEk esaten zuen bezala, bere ondorioak badituela. Dena den, argi utzi behar dugu ETELk ez duela eskubide hitza 9. artikuluan aipatzen.

Beraz, azken bi artikulu hauek udala egituratzen dute izaera politikoa duen autonomiaren esparruan. Hau horrela, badirudi ETEL finagoa dela ETAHaren toki autonomia kontzeptua definitzen eta errespetatzen, Espainiako antolamendu juridiko-konstituzionala baino. Udala erakunde demokratikoa izanik demokrazia printzipioetan oinarria dauka. Oso aipagarria da, eta adierazgarria aldi berean, zenbat aipamen egiten dituen ETELkToki Autonomiaren inguruan. Aipamen horietan guztietan ETAHk zehazten duenari aipu zuzena egiten dio, Estatuaren berme erakunde kontzeptua alderatuz eta Toki Autonomiari izaera politikoa aitortuz.

\section{III.1. Auto-antolakuntza}

Toki Autonomiaren adierazleetariko bat da Udalak berak bere kudeaketarako behar duen antolakuntza eratzea, hots, auto-antolakuntza. Gai horri dagokionez, ETELk argi dauka Udalak berak zehaztu behar dituela bere eskumenak, eta horien egikaritza gauzatzeko behar duten antolakuntza administratiboa eta instrumentala eratu behar duela. Zentzu horretan Legearen 10.1 artikuluak hurrengoa adierazten du: «Tokiko Autonomiaren Europako Gutunean(26) xedatutakoari jarraituz, udalerriek berek ezarriko dituzte be-

(26) Tokiko Autonomiaren Europako Gutuna bezala adierazten dena guk artikulu honetan Europako Toki Autonomiari buruzko Hitzarmen bezala adierazi dugu. 
ren eskumenak baliatzeko behar dituzten antolamendua eta administrazioeta instrumentu-egiturak, horrela, gobernu eta administrazio onaren printzipioa benetan gauzatzeko, eta baliabide publikoak finantzatzen jasangarritasunaren aldetik modu eraginkor eta efizientean kudeatzeko.».

Udalek eurek eratu behar dituzte haien egitura propioak, beti ere, oinarrizko araubidea kontuan harturik, horrela agintzen baitute ETELren 10.2 artikuluak eta 25.1 artikuluak. Horren harira ETELk argi markatzen du zein garrantzitsuak diren Udal Antolaketarako eta Funtzionamendurako Araudi Organikoek. Tresna horren garrantzia antolatzeko eta Toki Erakundeen funtzionamendurako eztabaidaezina da, eta horretan Udal bakoitzak araubide orokorra erabiliz haien antolaketa propioa eratzeko aukera ematen du.

Egia da tresna hori eta adierazpen horiek ez dutela inolako berrikuntza suposatzen, TAOLak berak jasotzen baititu 1985. urtetik, halabaina, ETELren berrikuntza erabilitako terminologian eta justifikazioetan dauka oinarri. ETELk udal antolaketa horri legitimazio demokratikoa ematen dio, eta demokrazia printzipioetan oinarritzen duen momentutik hasita bere izaera politikoa ere aitortzen da.

Horrez gain, auto-antolakuntza horren barruan Udalek euren zerbitzu eta eskumenak garatzeko elkartu daitezke, eta elkarlan horretarako edozein elkarte formula erabiltzeko aukera izango dute. Ezer berririk dakarren aipamen hau berrikuntza gisa jasotzeak justifikazioa dauka: elkarte horiek gauzatu behar dira ETAHk esandakoari jarraituz eta bi printzipio nagusietan oinarriturik: sorozpidetasuna eta herritarrari hurbiltasuna. Bi printzipio horiek azken finean Toki Autonomiarekin batera ematen diren printzipioak dira.

\section{III.2. Eskumen banaketa}

Eskumen banaketa ere Toki Autonomiaren adierazleetariko bat da, eta horrez gain, deszentralizazio izaeraren inguruko erakuslea. Gogoratu behar dugu: Alde batetik, Espainiako antolamendu juridikoaren eskumen banaketa izaera bifrontea duela, KAren 214/1989 Epaiak argitu zuenez eta horren arabera Udalen Eskumenak Estatuak eta Autonomi Erkidegoak euren legeen bitartez zehaztu behar dituztela; bigarrenik, Toki Administrazioaren Arrazionalizazioari eta Jasangarritasunari buruzko 27/2013 Legearen (hemendik aurrera TAAJL) ostean egonkortasunaren eta jasangarritasunaren izenean Toki autonomia gutxienera murriztu dela, batzuetan ikusezina bihurtuz(27); eta azkenik, ETELk toki autonomiaren in-

(27) ZOCO ZABALA, C, "Articulación de las competencias locales tras la LRSAL: hacia una autonomía local como derecho", Revista Vasca de Administración Pública aldizkarian, 102 zkian, 2015eko maiatza-abuztua, 107 orrian. 
guruan hitz egiterakoan denbora guztian ETAHk esandakoari jarraitzen diola.

Hau horrela, ETELk egin duen eskumen banaketa TAAJLren ondorioz TAOLak 7 eta 25. artikuluetan egindakoaren oso antzekoa izan da. Alde batetik, udalek euren eskumen propioak dituzte, 17. artikuluan zerrendatutakoak; bestetik, delegatutako edota transferitutako eskumenak daude; eta azkenik, udalari berez ez dagozkien eskumenak aurki ditzakegu. Eskemak beraz, ez du Estatuaren oinarrizko arauketaren kontra egiten, eskema berdina da. Eskema horretan eta ETELren 14. artikuluak adierazten duen bezala, errespetatuko dira jasangarritasun eta egonkortasun printzipioak.

Horiez gain, bestelako printzipio batzuk maila berdinean jartzen ditu ETELak 14.5. artikuluan: finantza nahikotasuna, herritarrari hurbiltasuna, sorozpidetasuna eta diferentziazio printzipioak.

Berrikuntza bi alderditik dator; alde batetik, eskumen propioetan, horien zerrendaketa Estatuak TAOLan planteatutako zerrenda baino askoz handiagoa da, eta ahalmen gehiago eta definituagoak ematen ditu; eta bestetik, berezkoak ez diren eskumen horiek egikaritzeko aukera izan dezaten 16. artikuluan aipatutako eskumen klausula unibertsalean eta horretan aplikatu beharreko printzipioetan.

Esan dezakegu, inolako beldurrik gabe, Euskadiko Legegileak Europako Kontseiluaren Ministro Batzordearen 1995eko urriaren 12ko R (95) $19 \mathrm{E}$ zenbakidun Gomendioa jarraitzen duela. Gomendio horretan sorozpidetasun printzipioaren aplikagarritasunean eskumen banaketa garbia eskatzen da, printzipio horrek eskumenen arteko harremana gidatuz. Hau horrela, ETELak eskumen propioen zerrenda handia jorratzen du, hori modu orokorrean arautuz eta sektorekako legegile edo araugilearen eskuetan sorozpidetasuna bermatuz. Eskakizun hori ere egiten zen 1998ko irailaren 18ko R (98)12 zenbakidun Ministro Batzordearen Gomendioan.

\section{Eskumen propioak}

Eskumen propioei dagokionez ETELren 17. artikuluak 37 gai desberdin aipatzen ditu, eta ez bakarrik hori, gai bakoitzean udalak duen ahalmenak ere zehazten ditu, udalak jakin dezan bere eskumenak antolatzeko, planifikatzeko, kudeatzeko, ikuskatzeko edota exekutatzeko baldin bada. Legeak beren-beregi aipatzen du zein eskumen zehatz dituen udal bakoitzak aipatzen diren 37 gai desberdin horietan. Adibide moduan Legeak 37.10 artikuluari jarraituz osasun publikoa sustatzeko, kudeatzeko, defendatzeko eta babesteko eskumenak izango ditu. Osasun publikoari buruzko gaian zeintzuk eskumen jorratu ahal dituen aipatzen ditu Legeak.

ETELren 17.2. artikuluaren arabera toki administrazioaren autonomia bermatzeko asmoarekin eskumen propioak ematen dituzten foru arauek 
edo EAEko Legebiltzarraren legeek bermatu behar dituzte aurreko puntuaren 37 eskumen eta gaietan aipatzen diren funtzioak eta ahalmenak. EAEko legeek eta Lurralde Historikoen Foru Arauek ezin izango dute muga hori gainditu haien arau sektorialetan eskumenak banatzen dituenean, eta aldarrikapen hori egiten da Toki autonomiaren izenean. Lurralde historikoek edota EAEak horiek mugatu nahi badituzte bi printzipio nagusi errespetatu behar dituzte: sorospide edo subsidiaritate printzipioa eta proportzionaltasun printzipioak.

Lurralde historikoaren eremutik edo EAEaren eremutik etor daitezken arau eskumen emaile horientzat ETELren 18. artikuluak betekizun zehatzak ezartzen ditu:

-Eskumenaren komenigarritasunaren esleipena ETELren 14.5. artikuluak aipatzen dituen printzipioei jarraituz eta batez ere sorozpidetasun eta hurbiltasun printzipioei jarraituz.

- Lege edo foru arau eskumen-emaile horien garapenean ere printzipio berdinak jarraitu behar dira, nahiz eta hori araudien bitartez egin. Araudi horiek eskumen eta zerbitzuen konkreziorako erabiliko dira.

- Arau eskumen-emaileetan edo horien konkreziorako garapen araudietan udalen finantza nahikotasuna bermatzeko beharrezkoak diren eta ematen diren baliabideak zehaztu beharko dira.

- Arau eskumen-emaile horiek ahalmenak eta funtzioak definitzerakoan bermatu behar dute ez dela inolako bikoiztasunik emango 16 . artikuluarekin bat etorriz.

Beraz, eskumen propioen inguruan ETELren helburua, horien egikaritza eragingarria bermatzea da, herritarraren hurbiltasuna eta sorozpidetasuna bultzatuz ETAHk zehazten duen moduan, eta ahaztu gabe finantzanahikotasuna eta toki autonomia batera joan behar direla.

Propioak, delegatuak edo transferitutakoak ez diren bestelako eskumenak:

ETELan propioak, delegatuak edo transferituak ez diren bestelako eskumenak (hemendik aurrera bestelako eskumenak deituko ditugunak) 27/2013 Legearen 7.4 artikuluaren eskeman barneratzen dira, baina hauen inguruan EAEko Legeak berregituratze bat egiten du. ETELren 14.4 artikuluak zera adierazten du: «Era berean, toki-erakundeek eskumen propio, transferitu edo eskuordetuetan sartzen ez den beste edozein jarduera, zerbitzu edo prestazio garatu ahal izango dute tokiko komunitatearen intereserako, baldin eta, lege honetan azaldutakoaren arabera, bikoiztasun egoerarik sortzen ez bada eta erakundearen ogasun osoaren finantza-jasangarritasuna arriskuan jartzen ez bada.». Eskema berdina beraz Esta- 
tuko oinarri legerian eta ETELan, baina Estatu legeriaren asmoa horien murriztapena den heinean (gogoratu behar dugu TAOLren 28. artikulu zaharra indargabeturik gelditu dela eta 25.1 artikulua berridatzi egin dela), ETELk horien garrantzia bultzatu egiten du.

Bultzada horretan lan egiten du ETELren 16. artikuluak izenburu moduan hurrengoa duena: Klausula unibertsala udal-eskumenei buruz eta eskumen propio, transferitu edo eskuordetu ez direnen jarduera, zerbitzu edo prestazioei buruz. Titulu honen azpian aurkitzen dugu Toki autonomiaren aldeko beste apustu bat, bertan adierazten delako herritarren bizi kalitatea hobetzeko eta komunitatearen interesak edo beharrizanak asetzen dituen bestelako zerbitzu edo eskumenak ere garatu ahal dituela Udalak, nahiz eta horiek ez egon eskumen propioen, eskuordetuen edota transferitutakoen jarduera esparruan. Egia da, eskumen horien egikaritzarako bikoiztasunak saihestu behar direla eta finantza-jasangarritasuna bermatu behar direla, baina printzipioz ez dago inolako arazorik eskumen mota horiek eman ahal izateko Toki erakundeen autonomia indartuz.

Aipatutako bi baldintzen inguruan 16. artikuluak zera aipatzen du:

- Bikoiztasunei buruz: Legeak bikoiztasuna zer den azaltzen du artikuluaren 3. puntuan eta bikoiztasuna ematen da bi lurralde erakunde ezberdinak eskumeneko gai berdinean funtzio publiko berdinak ematen dituztenean, lurralde eremu berdinean edo herritar kopuru berdinean eta beharrizan berdina asebetetzeko. Hau horrela, bikoiztasunak saihesteko helburuarekin, toki erakundeek ezin izango dute eskumenik edo zerbitzurik garatu, eskumen edo zerbitzu horiek beren-beregi antolamendu juridikoak beste lurralde administrazio bati aitortzen badizkio.

Baina legeak bikoiztasuna definitu eta bikoiztasunak saihesteko helburua izanik, bikoiztasuna ematen ez den kasua ere aipatzen du, eta horren arabera, ez dago bikoiztasunik zerbitzu edo eskumena ematen denean beste administrazio baten berariazko finantzazioaren bitartez edo beste administrazio horiek garatutako programak jarraitzen direnean. Beraz bikoiztasun kontzeptua ondo definituta dago eta ez da TAOLean 27/2013 Legeak sartutako kontzeptu murriztatzailea.

- Finantzazioari dagokionez Legeak argi uzten du bakarrik gauzatu ahal direla bestelako eskumen hauek udalak berak finantzatu ahal badu, eta beti ere, udalak aurrekontu egonkortasuna eta finantza-jasangarritasuna bermaturik baditu, nahiz eta Udalak Plan ekonomiko-finantzarioa izan. Modu horretara badirudi 16.5. artikuluak Udalaren erantzukizunpean uzten duela, ETAHren 3.2. artikuluak eskatzen duen udal jardueraren erantzukizuna sustatuz. 
Azkenean artikuluak gaiaren arabera administrazio sektorialaren eskuetan uzten du bikoiztasunaren inguruko txosten loteslea egitea, eta finantza-zaintza organoaren eskuetan uzten du finantza-jasangarritasunaren txostena egitea.

\section{III.3. Herritarren parte-hartzea Udalak jorratzen dituen politiketan}

Bigarren epigrafean aipatu dugun bezala herritarren parte-hartzea ETAHren toki autonomiaren zatia da eta horren adierazle zuzena. Ez dugu ahaztu behar toki erakundeen helburu nagusia ETAHren esanetan eta EKren 137. artikuluaren esanetan herritarren intereserako diren gaiak asebetetzea dela. Hau horrela, herritarren parte-hartze zuzenaren aldeko apustua egiten da. ETEL oso sentsiblea da gobernantza politika eta gobernu ireki politika berriekin eta horren adierazlea da ETELk berak, beren ikuspuntua toki administrazioan islatuz.

Zentzu horretan ETELren 43.1.b). artikuluak herritarren eskubideak aipatzerako orduan zera adierazten du: «b). - Tokiko politika publikoak identifikatzen, prestatzen, kudeatzen eta ebaluatzen, eta herri arazoetan parte-hartzea, legeek, udal erregelamendu organikoek eta herritarren parte-hartzeari buruzko erregelamendu organikoek ezarritakoarekin bat etorrita..... Herritarrak udal gaietan parte-hartzeko eskubidea dute ez bakarrik hauteskundeen bitartez ordezkariak hautatuz, baizik eta politika publikoen diseinuan eta horien garapenean ere. Horretarako, legeak berak II. tituluko IV. kapituluan herritarren partaidetzari buruzko arauketa egiten du, ETELren 67. artikuluak zehazten duen helburuarekin: benetako herritarren parte-hartzea bermatu. Legeak 69. artikuluan pate-hartzearen helburuak zehazten ditu:

- Herritarrak politika publikoetan jarrera aktiboa izatea.

- Arau eta plan desberdinetan parte-hartzea.

- Toki gobernuko organoen erabakietan eta prozedura administratiboetan parte-hartze aktibo izatea.

Parte-hartze horren gutxienekoa ETELan zehazten da, baina auto-antolakuntzaren esparruan uzten du parte-hartze horren zehaztapena. Horrek ETELak esaten duena errespetatu behar du, baina udal arau propioek zehaztuko dituzte prozedura desberdinak, lehentasunez (esaten du legeak) udal araudi organikoan. Argi dago ETELk gutxieneko bat arautzen duela 3 esparru ezberdinetan zatikaturik:

\section{Partaidetza prozedurak}

Partaidetza prozedurek bi helburu desberdin dituzte; alde batetik parte-hartze eragingarria sustatzeko informazio prozedurak, eta bestetik, poli- 
tika publiko baten inguruan edo erabaki baten inguruan sustatutako eztabaiden emaitza, legeak 75 . artikuluan partaidetzako deliberazio prozedurak deitu duena.

Arau mailako xedapenak egiteko prozesuetan parte hartzea

Izen horrekin ETELk herritarren ekimen araugilea identifikatzen du, edo udal mailako arauen idazketan herritarrek izan dezaketen parte-hartzea. Adierazgarria da artikulu konkretu bat ezartzen dela udal aurrekontuen idazketan herritarren partaidetza sustatzeko.

\section{Beste partaidetza tresnak}

Honen barruan legegileak 3 tresna ezberdin aipatzen ditu: Herri galdeketak, auzo intereserako garrantzitsuak diren eskumen propioen inguruko gaien inguruan; Sektoreko edo lurralde-eremu mugaturako galdeketak, arazo konkretu baten inguruan bakarrik herritarren zati bati eragina izango duten gaiak tratatzeko; eta politika publikoei edo garrantzi bereziko erabaki publikoei buruzko toki-mailako herri galdeketak.

Parte-hartzeari buruzko arauketa handia egiten du ETELk baina gogoratu behar ditugu orain Estatuaren eta EAEko Administrazio Elkarlanerako Aldebiko Batzordearen $\mathrm{G}$ eta J bitarteko puntuetan (28) herri parte-hartzearen inguruan egin diren ohartarazpenak. Horien arabera kontsultak eta parte hartze prozeduren emaitzak ez dira lotesleak izango, TAOLak adierazten duen moduan, eta azkeneko erabakia udalbatzaren osoko bilkuraren gain eroriko da, parte hartze deskafeinatua utziz.

\section{III.4. Udalaren parte-hartzea beren interesean eragina izan dezaketen politiketan}

Baina parte-hartzea beste bide baten ere jorratzen du ETELk. Udalek euren intereserako diren zerbitzu eta eskumenak jorratzeko aukera ematen badu ETELk, lege horrek berak, zehazten du eskumen banaketan eta udal intereserako garrantzitsuak diren gaietan udalek izango duten parte-hartzeko aukera. ETELk berak bi organo eratzen ditu EAEko erakundeek euren politika publikoak egituratzerakoan Udalek parte hartu dezaten.

(28) ETELren inguruan Estatuaren eta EAEko Administrazio Elkarlanerako Aldebiko Batzordeak akordioa lortu egin zuen eta argitaratu egin zen EAEko Aldizkari Ofizialean, 2017ko otsailaren 17an. 
- Tokiko Politika Publikoen Euskal Kontseilua.

- Euskadiko Tokiko Gobernuen Kontseilua.

Bi organo horien bitartez bermatu nahi da udalen parte-hartzea politika publikoetan eta arauetan. Aztertu ditzagun bi horiek banan-banan, helburu berdina izan arren izaera desberdina eta jarduteko modu desberdinak dituztelako. Bestetik ETELren 92. artikuluak antzeko organoak lurralde historikoetan eratzeko aukera ematen du udalen intereserako gaien inguruan udalen parte-hartzea bermatuz; baina, artikulu horrek aukera besterik ez du ematen eta beraz, ez ditu derrigortzen. Lurralde historikoen eskuetan geldituko da organo horiek eratzea edo ez.

\section{a) Tokiko Politika Publikoen Euskal Kontseilua}

Erakunde honen helburu nagusia da ETELren 83. artikuluaren arabera tokiko gobernu-eremuari eragiten dioten politika publikoak diseinatu, prestatu, burutu eta ebaluatzeko prozeduretan udalerrien interesak aitortu eta aintzat hartuko direla bermatzea. Horrez gain, beren eskumena izango da EAEko erakunde erkideei dagozkien eskumenen gaineko erabakiak hartzea, baldin eta udalerrien eskumen propioen esparru materialari eragiten badiete. Hau da, EAEak udalerrien eskumen propioen inguruan erabakiak hartu behar dituenean edota politika publikoak diseinatzerakoan Udalen interesak kontuan hartuko dituen organoa izango da.

Beraz, zalantzarik gabe Toki Autonomiaren apustua indartzen du, organo honen eraketan bermaturik geratzen delako Udalen parte-hartzea EAEko eta Lurralde Historikoetako politika publikoak sortzerako orduan. Eta horrela agertzen da 84. artikuluan, erakundearen izaera politikoa definitzerako orduan. Horren arabera, Tokiko Politika Publikoen Euskal Kontseiluak egitura parte-hartzailea dauka toki autonomia bermatzeko helburuarekin.

EAEko organo honen osaeran ere toki autonomiaren bermea aurkitzen dugu, bere 18 kideetatik sei udalen ordezkaritza izango dutelako eta ezarpen handiena duen euskal udalerrien elkarteak proposatuko ditu. Horrez gain kide horietatik bik (herena dio legeak) 5.000 biztanle baino gutxiagoko udalerrien hautetsiek beteko dituzte. Lehenengo lau urterako izendapenak egin ziren Lehendakariaren uztailaren 22ko 20/2016 Dekretuaren bitartez.

Organo honekin amaitzeko beren funtzioen laburpena egitea komenigarria da, horiek ikusita argi geratzen delako zeintzuk diren beren eginkizunak:

- Autonomi Erkidegoak egingo dituen plan eta programetan parte hartuko dute, beti ere udalerrien eskumen propioei eragiten diete- 
nean. Horren inguruan txostenak egin ahal izango dituzte eta lege eta egokitasun irizpideak adierazi ahal izango dituzte.

- Euskadiko Tokiko Gobernuen Batzordeak eskumen propioei eragiten dieten araugintza bultzatzeko proposamenak bideratu ahal izango ditu.

- Euskadiko administrazio ezberdinen arteko elkarlana eta informazioa trukaketa bultzatuko dute.

- Udalerrien eskumenei eragiten dieten politika sektorialen inguruan eztabaidatu eta komunean jarri.

- Gobernu maila ezberdinen politika publikoen kudeaketarako kooperazio sistemak sustatuko dituzte.

-EAEko gobernuari konstituzioaren aurkako helegitea jartzeko eskatu.

Beraz, organo honen bitartez, eskumen propioen zehaztapena eta horien garapenean udalerrien parte hartzea bermaturik geldituko da, eta horrekin toki autonomia indartu egingo da ETAHk ezartzen duen Toki autonomia printzipioa zehaztuz, eta EKren 137. artikuluko "berezko gaiak» kontzeptua garatuz.

\section{b) EUSKADIKoTOKI Gobernuen BATZORDEA}

Euskadiko Toki Gobernuen Batzordea sortzen da alerta goiztiarreko organo gisa, hau da, beren helburu nagusia da EAEren araugintza-prozeduretan toki autonomia zaintzea, lege horrek edo indarrean dagoen legeriaren gainerakoak udalerriei aitortutako eskumen propioei soilik eragiten dieten kasuetan. Hau da, EAEko legeriak udalen eskumen propioak kaltetzeko "arriskua» dutenean Batzordeak esku hartuko du toki autonomiaren defentsa bermatzeko.

Batzordeak 12 kide izango ditu, horietatik sei Toki Politika Publikoen Euskal Kontseiluaren udal ordezkaritzako kideak izango dira; eta beste seiak, udaletako hautetsien artean aukeratuko dira, baina horietatik bik 5.000 biztanle baino gutxiagoko udalerrien ordezkariak izango dira.

Batzorde honen helburu nagusia da 88. artikuluaren arabera toki autonomiaren defentsa, eta hurrengo eginkizunak izango ditu:

- Alerta goiztiarreko organo bezala jarduteko eta araugintza prozeduretan toki autonomiaren defentsa bultzatu.

-Xedapen orokorren aurreproiektuen prestakuntzan parte hartzea ETELren 91. artikuluak zehazten duen prozeduraren barruan.

- Udal estatu gaitasuneko langileen, goi karguen eta politikoen ordainsarien eta bertaratzeen inguruan proposamenak eta azterlanak egitea eta horiek Toki Politika Publikoen Euskal Kontseiluari helarazi horien inguruan irizpena egin dezaten. 
- Toki zerbitzu publikoen kostu eraginkorraren gainean azterlanak eta proposamenak egitea.

- Aurrekontu egonkortasunari buruzko arauetan adierazten diren plan ekonomiko finantzarioen formulazioaren inguruan proposamenak et azterlanak egitea.

Deigarria da nola ETELren 91. artikuluan adierazten den xedapen orokorreko aurreproiektuen eta proiektuen inguruan Batzorde honek derrigorrez txostena egin behar duela, EAEko araugintzan toki autonomiaren bermatzea gauzatuko dela ziurtatzeko. Egia da, era berean, txostena egiteko 15 eguneko epea ematen diola legeak Batzordear, eta arau bakoitzaren izaera eta garrantzia ikusirik epe laburra dirudiela, baina aukera behintzat badago lan hori gauzatu eta toki autonomia eta eskumen propioen defentsa gauzatu ahal izateko.

\section{III.5. Finantza-nahikotasuna}

Azkenik, lehenengo epigrafeetan behin baino gehiago esan dugunez, toki autonomiak ez dauka zentzurik finantza-nahikotasunik gabe, hau da, autonomia ezin daiteke garatu beharrezkoak diren baliabideak ez badira bermatzen. Udalen finantzazio sistema beti izan da arazo bat. Zerga eta tasa propioekin ez da udal jarduera finantzatzen eta horretarako lurralde historikoen diru-bilketatik finantzazioa jasotzen dute. Orain arte EAEko lurralde historikoek zehaztu dute zein ekarpen ekonomiko egingo zaien udalei. ETELk IX. tituluan toki erakundeen finantzazioari buruz hitz egiten du, eta horretan adierazten denez: "EAEko udalerriek eta gainerako toki-erakundeek ekonomiaren arloan izango dituzten eskubide eta betebeharren multzoak osatuko dute toki ogasuna» eta jarraian lurralde historikoen eskumena berretsi egiten du gai horretan lurralde historikoen foru arauen bitartez toki ogasunak arautzen direlako. Baina, zehazten ditu toki ogasun horiek errespetatu behar dituzten printzipioak: finantza autonomia, aurrekontu egonkortasuna eta finantza-jasangarritasuna, eta finantza-nahikotasuna. Azken printzipio horren arabera udalek beren eskumenak garatzeko beharrezkoak dituzten baliabideak izan behar dituztela aitortzen da.

Baliabide nahiko izateak derrigortu egiten dio ETELri 110. artikuluan hurrengo baieztapena egiteko: "Orokorrean, udalerrien eta gainerako tokierakundeen finantzaketa baldintzarik gabekoa izango da». Hau da, printzipio orokor bezala udalaren finantzazioan ezin daiteke inolako baldintzarik jarri eta horrek suposatzen du inork ezin diezaiekela esan udalari zertan edo zein baldintzatan erabiliko dituen finantzazio horiek. Hau horrela, 112 artikuluak esaten duenez, lege edo foru arau baten udalerriari edo tokierakundeei eskumenak aitortzen edo ematen bazaizkio beharrezko finantzazio-baliabideak ere zehaztuko dira zerbitzuak emango direla berma- 
tzeko eta horrekin lotuta legearen edo foru arauaren proiektuarekin batera memoria ekonomikoa aurkeztuko da jakiteko zer nolako eragin ekonomikoa izango duen eskumen banaketa hori toki ogasunetan.

Modu honetan eskumen bat banatzen den momentuan eskumen hori garatzeko behar besteko baliabideak ere etorriko dira udalaren jasangarritasuna kolokan jarri gabe, eta finantza-nahikotasunaren bitartez toki autonomia bermatuz.

Salbuespenez, bakarrik ezarri daiteke baldintzatutako finantzazioa arau xedapen baten bitartez edo diru-laguntza politikaren bitartez, hurrengo printzipioak jarraituz:

- Toki-erakundeen parte hartzea.

- Aurrekontu egonkortasuna eta finantza-jasangarritasuna.

-Efizientzia, efikazia eta zerbitzu publikoen kalitatea.

Azkenean, IX. tituluko II. kapituluak arautu egiten du udalen parte-hartzea itunduko tributuen etekinetan eta udal finantzazioan.

\section{Ondorioak}

EAEko legegileak ETELren bitartez esfortzu handia egin du toki autonomiaren defentsarako toki administrazioak arautzen, horrela toki erakundeen izaera politikoa eta antolatzailea behar bezala babesteko tresna garaturik izango dute, behintzat EAEko lurralde mugartean. Baina egia da, era berean ETEL Konstituzio Auzitegian errekurritu egin zela, eta errekurtsoa kentze aldera Eusko Jaurlaritzak akordioa sinatu zuela Estatuaren eta EAEko Administrazio Elkarlanerako Aldebiko Batzordearen baitan. Ez gara hemen sartuko akordio horien indarraren inguruan, baina badirudi izaera legegilerik ez duen akordio horiek Legearen interpretazioaren bitartez horien berridazketa gauzatu dezaketela legebiltzarretik pasa barik. Akordioak ez dira legebiltzarretik pasatzen, administrazioen arteko akordioak direlako, baina legegileak onartutako legeak «mutatzeko» aukera zabaltzen dute.

2017ko otsailaren 17an EAEko Aldizkari Ofizialean argitaratutako Estatuaren eta EAEko Administrazio Elkarlanerako Aldebiko Batzorde akordioaren arabera, gai batzuen inguruko eragingarritasuna mutatu edo aldatu egiten du edo "indarra» galtzen dute: herritarren parte-hartzeari dagokionez, esate baterako, 68, 80 eta 82 artikuluen interpretazioa aldatu egiten da, eta horrekin legearen testua bera; 16 urtetik beherakoek ezin izango dute herri kontsultetan parte hartu TAOLrekin interpretatu behar delako ETEL, eta egiten diren prozedura parte-hartzaile guztiak ez dira lotesleak izango, nahiz eta beren-beregi hori ETELn adierazi. Eskumen propioen esparruan ere ETEL TAOLrekin interpretatu behar da, eta euskara 
sustatzearen eta administrazio erabileraren (udal eskumen propioaren gaia) inguruko arauketa deskafeinaturik geratzen da.

Dena den, toki autonomiari dagokionez EAEko legegileak egin duen esfortzua txalogarria da, eta argi eta garbi adierazten du udala modu ezberdinean ulertzeko betebeharra dagoela, krisi aurretik goraipatzen zen toki autonomiarantz berriro bideratuz.

Baina arau honek ez du mirari handirik egingo, eta beren arazoak ere baditu. Lehenengoa eta adierazgarriena da garapen handia behar duela, eta beste arau batzuk behar izango dituela benetako garapena izateko. Araudi bitarteko garapen handia behar du, eta araudi horiek egiten ez diren bitartean ez da legea ehuneko ehunean martxan jarriko. Legearen garapena EAEko exekutiboak berak eta Foru Administrazioak gauzatu beharko dute, baina baita Udal Administrazioak ere (Toki Erakunde guztiak egia esan) legearen benetako eragingarritasuna gauzatzeko horren garapenean parte hartu beharko dute. Horren adierazlea da Euskadiko Toki gobernuen Batzordea oraindik eratu barik dagoela eta Lurralde Historikoek ere alerta goiztiarrerako organoak sortzeko aukera ere zabaldu behar dutela. Hau da EAEko alerta goitiarrerako organoa oraindik eratu barik dago eta ETELk Lurralde Historikoetan izaera berdineko organoa sortzeko tresnak oraindik ere ez dira martxan jarri.

Dena den, kontuan izan behar dugu ETELk orain arte bere buru gainean aizkora izan duela Konstituzio Auzitegiaren aurrean aurkeztutako errekurtsoekin, eta orain hasiko dela Estatuaren eta EAEko Administrazio Elkarlanerako Aldebiko Batzordearen akordioa eta gero bere hedadura guztia zabaltzen.

Bestetik, ETELak erakunde egituraketa itxi egiten duela eta toki autonomia babesteko ahalegin handia egiten duela, baina udal langile bezala TAOLean oinarrizkoak bezala jartzen diren gauza asko ez dira garatzen. Faltan botatzen da, esate baterako, udalerrien ondasunen kudeaketari buruzko arauketa sakona egitea, finantza-nahikotasunarekin harreman handia duelako eta udalen finantzazio bidea izan daitezkeelako. Egia da honen inguruan estatu arauak daudela Herri Administrazioaren Ondareari buruzko 33/2003 Legea edo, udaletan hain erabilia den Toki Erakundeen Ondasunei buruzko Araudia (1732/1986 ED), baina bi arau horiek zaharkituta gelditu dira, eta horren adierazlea da esate baterako, Toki Erakundeen Ondasunei buruzko Araudiaren 92.artikulua alokairuan ondare ondasuna ematen direnean prezioen inguruan egiten den arauketa.

Beraz, toki autonomiaren defentsan, deszentralizazio politikoaren bidean eta Toki Erakundeen «burujabetasunaren» aldeko apustu argia egiten da EAEan ETELarekin, baina beren izaera egituratzaile guztia garatzeko oraindik ahalegin handia gelditzen da eta hori guztia garatzen denean, orduan benetako ETAHren toki autonomiaren aurrean egongo gara. 


\section{Bibliografia}

ÁLVAREZ RICO, M., Principios Constitucionales de organización de las Administraciones Públicas, Instituto de Estudios de Administración Local, 1987, 37 orr.

Diccionario de la Real Academia de la Lengua Española, edición del tricentenario. www.rae.es.

COLAO MARÍN, P. A., Autonomia municipl, ordenanzas fiscales y reserva de ley, Bosc Editor, 2011, Bartzelona.

LAGO MONTERO, J.M., La reordenación de la Hacienda Local en la segunda descentralización, Thomson Aranzadi ed., 2013, ZizurTxikia.

LASAGABASTER HERRARTE, I., La Carta Europea de la Autonomía Local, iustel, Madril, 2007.

ORDUÑA REBOLLO, E., eta COSCULLUELA MONTANER, L., Historia de la legislación de régimen local, lustel, 1 edizioa, Madril, 2008, 198. Orrian

PARADA VÁZOUEZ, R, Derecho Administrativo I (Organización y empleo público), Marcial Pons, 1988, 196 orr.

PÉREZ LUQUE, A, ¿Existe realmente la autonomía local? El consultor de los Ayuntamientos, 14 zkia, 2002ko uztailaren 30etik abuztuaren 14rako hamabostaldia, bigarren liburukia, 2437 orria.

REQUEJO PAGES, J L., "El valor de la Carta Europea de la Autonomía Local en el ordenamiento español" La autonomía de los entes locales en positivo: La Carta Europea de la Autonomía Local como fundamento de la suficiencia financiera liburuan (CAAMAÑO DOMíNGUEZ, F Koord.), Ed. Fundación Democracia y Gobierno Local, Madril, 2003.

SÁNCHEZ SAEZ, A.J., Autonomía Local y Descentralización, Su naturaleza jurídica, Tirant Loblanc, Valentzia, 2008, 23 orria.

ZOCO ZABALA, C, «Articulación de las competencias locales tras la LRSAL: hacia una autonomía local como derecho", Revista Vasca de Administración Pública aldizkarian, 102 zkian, 2015eko maiatza-abuztua, 107 orrian.

KAren 32/1981 Epaia.

KAren 41/2016 epaia, 1792/2014 Errekurtso zenbakia.

AGaren 1987ko urriaren 28ko eta abenduaren 28ko epaia.

Trabajo recibido el 24 de marzo de 2017

Aceptado por el Consejo de Redacción el 26 de mayo de 2017 
LABURPENA: Azken urteotan badirudi Toki Autonomia indarra galtzen joan dela beste printzipio batzuekin alderatuz, konkretuki aurrekontu egonkortasun eta finantza-jasangarritasunarekin. Bi printzipio hauek Toki Administrazioaren azkenengo erreformak baldintzatu dituzte. Baina aurreko urteko apirilean Euskadiko Toki Erakundeei buruzko apirilaren 7ko 2/2016 Legea (ETEL) argitaratu zen eta horrekin EAEko toki erakundeen autonomia indartzeko ahalegina egin zen. Lege hau da ahalegin horren produktua, eta horretan Toki Autonomiaren aldeko apustua egin da EAEk duen udal izaera eta garapena kontuan izanda. Gaur egun indarrean jarraitzen duen apustu horren adierazle handiak aurki daitezke legean zehar, Europako Toki Autonomiaren Hitzarmenarekin bat eginez eta udalerrien autonomia indartuz. Lan honetan toki autonomiaren adierazle diren ezaugarriak hartu eta ETELan duten isla aztertzen da.

GAKO HITZAK: Toki autonomia. Eskumena. Erakunde bermea. Parte-hartzea. Berezko gaien kudeaketa.

RESUMEN: Parece que en los últimos años la autonomía local ha ido cediendo fuerza en favor de otros principios como son la estabilidad presupuestaria y la sostenibilidad financiera. Estos son los principios que han impulsado las últimas reformas sobre la Administración Local. Pero en abril del año pasado se publicó la Ley $2 / 2016$, de 7 de abril, de Entidades Locales de Euskadi (LILE) y con ella la CAV ha hecho un esfuerzo por impulsar la autonomía municipal. Esta ley es el producto de ese esfuerzo, donde a tenor de la naturaleza y concepción que la CAV tiene del municipio se ha apostado por la autonomía local. A lo largo de la Ley se pueden ver las expresiones de dicha apuesta que hoy día sigue en pie y que refuerza la autonomía local inspirada por la Carta Europea de la Autonomía Local. En este trabajo se van a tratar los indicadores de autonomía local y su reflejo en la LILE.

PALABRAS CLAVE: Autonomía local. Competencia. Garantía institucional. Participación. Gestión de los asuntos propios.

ABSTRACT: It seems that during last years, local autonomy has yielded in favor of other principles as budget stability and financial sustainability. These are the principles that were bolstered by the last amendments on Local Administration. But last april it was published Act 2/2016 from April $7^{\text {th }}$ on Local Entities of Euskadi and with it the Basque Autonomous Community has made and effort to bolster municipal autonomy. This Act is the consequence of that effort where in terms of the nature and conception that the Basque Autonomous community has over municipality, local autonomy has been fostered. Under the Act you can see expressions of that support that to this day stand and strengthen the local autonomy inspired by the European Charter of Local Autonomy. In this work we are going to deal with the local autonomy indicators and its expression within the Act on Local Entities.

KEYWORDS: Local Autonomy. Competition. Institutional guarantee. Participation. Management of their own affairs. 